Марина

МЕДВЕДЄВА

\section{Права людини в умовах пандемії}

COVID-19 виявився справжнім випробуванням для суспільств, урядів, общин та індивідів [6]. Пандемія, спричинена розповсюдженням коронавірусу SARS-CoV-2, актуалізувала необхідність забезпечення прав людини в умовах надзвичайної ситуації, важливість належного обгрунтування встановлених обмежень цих прав, а також незворотності відповідальності держав за їх порушення.

Держави зобов' язані гарантувати кожному, хто перебуває під їхньою юрисдикцією, права і свободи, визначені у відповідних міжнародних договорах (наприклад, стаття 2 Міжнародного пакту про громадянські і політичні права, стаття 1 Конвенції про захист прав людини та основоположних свобод, стаття 1 Американської конвенції $з$ прав людини). Зазначене загальне зобов' язання деталізується щодо кожного окремого права, визнаного цими договорами. Стандарт поведінки держави у звичайних або надзвичайних обставинах щодо забезпечення поваги й дотримання прав людини визначається концепцією «належної обачності» (англ. - due diligence), яка проголошує, що держава повинна вживати всіх необхідних заходів та докладати максимальних зусиль для попередження порушень прав людини і реагування на такі порушення внаслідок будь-якої діяльності, що здійснюється під іiі юрисдикцією або контролем. У вітчизняній доктрині цю концепцію традиційно називають позитивною відповідальністю держави [1]. В умовах пандемії стандарт «належної обачності» передбачає обов' язок держав гарантувати, перш за все, право на життя та право на здоров'я для кожного без будьякої дискримінації.

Позитивне зобов' язання держави захищати людське життя і здоров' я передбачає, зокрема, своєчасне планування з метою попередження спалахів інфекційних хвороб та застосування негайних засобів у відповідь задля подолання наслідків епідемій [5]. Стаття 12 Міжнародного пакту про економічні, соціальні і культурні права деталізує стандарт «належної обачності» відносно права кожної людини на найвищий досяжний рівень фізичного і психічного здоров' я: держави зобов' язані вживати заходів, необхідних для запобігання та лікування епідемічних, ендемічних, професійних та інших хвороб і боротьби з ними, а також створення умов, які б забезпечували всім медичну допомогу і медичний догляд у разі хвороби. Подібні зобов'язання визначаються іншими міжнародними договорами із захисту прав людини (стаття 11 Європейської соціальної хартії (переглянутої), стаття 10 Додаткового протоколу до Американської конвенції з прав людини щодо економічних, соціальних та культурних прав («Сан-Сальвадорський протокол»), стаття 16 Африканської хартії прав людини та народів). Комітет ООН з прав людини розтлумачив зазначені зобов' язання як такі, що включають «створення системи невідкладної медичної допомоги у випадках ... епідемій» [4], а також забезпечення доступності відповідних технологій, належного використання та вдосконалення епідеміологічного нагляду та збору даних, здійснення програм з імунізації.

Відсутність або недостатність кроків, вжитих урядами різних держав, для інформування власної та світової громадськості про ризики, пов'язані з COVID-19, з метою визначення конкретних профілактичних та лікувальних заходів, а також ненадання необхідної медичної допомоги населенню можуть призвести до порушення позитивного зобов' язання держави застосувати міри, необхідні для захисту життя і здоров'я осіб, що перебувають під їі юрисдикцією [8].

Боротьба з COVID-19 виявила вразливість та незахищеність певних верств населення, таких як медичні працівники, особи з інвалідністю, з хронічними захворюваннями, люди похилого віку, мігранти, внутрішньо переміщені особи, біженці, національні, етнічні та релігійні меншини, корінні народи, діти, жінки, безхатченки, особи в місцях несвободи, бідні верстви населення, тощо. Важливо, щоб доступ до профілактичних та лікувальних заходів забезпечувався кожному без будь-якої дискримінації. Держава зобов' язана вживати заходів з охорони здоров'я в умовах пандемії без будь-яких розрізнень на підставі раси, кольору шкіри, статі, мови, національного чи соціального походження, майнового стану, віку, релігійних, політичних чи інших переконань. В резолюції Всесвітньої асамблеї охорони здоров'я від 18 травня 2020 року йдеться про те, що під час виконання національних планів

УДК: 341.176

https://doi.org/10.36952/uail.2020.2.70-73

(ㄷ) M. Meдведєва

\section{МЕДВЕДЄВА Марина}

д.ю.н., професор, професор кафедри міжнародного права Інституту міжнародних відносин Київського національного університету імені Тараса Шевченка 
дій з протидії COVID-19 держави повинні попереджати випадки насильства, дискримінації, стигматизації та маргіналізації [7].

Загальновідомо, що у випадках, пов' язаних з необхідністю забезпечення належного визнання і поваги до прав і свобод інших, охорони національної безпеки, забезпечення справедливих вимог моралі, громадського порядку та загального благополуччя в демократичному суспільстві, а також 3 метою охорони здоров'я держава може обмежити деякі права та свободи людини. Такі обмеження повинні бути передбачені законом; необхідними в демократичному суспільстві; переслідувати законну ціль; бути пропорційними [9]. На відміну від обмежень прав людини, які можуть відбуватись у звичайному повсякденному житті за умови дотримання вище означених принципів, міжнародні договори передбачають також можливість для держав здійснювати відступ від своїх зобов' язань (дерогацію) в сфері захисту прав людини в надзвичайних обставинах.

Стаття 4(1) Міжнародного пакту про громадянські і політичні права зазначає, що під час надзвичайного становища в державі, при якому життя нації перебуває під загрозою і про наявність якого офіційно оголошується, держави-учасниці можуть вживати заходів на відступ від своїх зобов'язань за Пактом тільки в такій мірі, в якій це диктується гостротою становища, при умові, що такі заходи не є несумісними $з$ їх іншими зобов' язаннями за міжнародним правом і не тягнуть за собою дискримінації виключно на основі раси, кольору шкіри, статі, мови, релігії чи соціального походження. В статті 15(1) Конвенції про захист прав людини та основоположних свобод (далі - Конвенція 1950 р.) передбачається, що під час війни або іншої суспільної небезпеки, яка загрожує життю нації, будь-яка Висока Договірна Сторона може вживати заходів, що відступають від іiі зобов'язань за Конвенцією, виключно в тих межах, яких вимагає гострота становища, і за умови, що такі заходи не суперечать іншим ії зобов' язанням згідно з міжнародним правом. Положення про дерогацію містяться також в статті F частини V Європейської соціальної хартії (переглянутої) і статті 27 Американської конвенції 3 прав людини.

Будь-яка дерогація повинна відповідати певним принципам: виключність загрози; пропорційність заходів; офіційне оголошення про надзвичайний стан та повідомлення про дерогацію; неможливість дерогації щодо окремих прав; заборона дискримінації; відповідність іншим зобов' язанням за міжнародним правом. Держава може відступати від своїх зобов' язань за міжнародними договорами $з$ прав людини лише тоді, коли стикається з ситуацією виняткової та фактичної чи неминучої небезпеки, яка загрожує життю нації. Загроза життю нації повинна впливати на все населення, а також на всю або частину території держави, і стосуватися фізичної цілісності населення, політичної незалежності чи територіальної цілісності держави [9]. Очевидно, що пандемія, пов' язана із розповсюдженням висококонтагіозних інфекційних хвороб з високими показниками смертності, відповідає визначенню такої загрози. В багатьох державах у зв' язку із коронавірусом було оголошено надзвичайний стан чи надзвичайну ситуацію. Саме оголошення надзвичайного стану є підставою для дерогації.

У зв' язку з пандемією коронавірусу кількість держав, які зробили заяви про дерогацію, є безпрецедентною. В рамках Пакту про дерогацію повідомили такі держави, як Вірменія, Гватемала, Грузія, Еквадор, Естонія, Латвія, Перу, Румунія, Чилі. Наприклад, Латвія відступила від зобов'язань за Пактом $з$ гарантування свободи пересування, права на повагу до приватного і сімейного життя, а також мирні зібрання; Вірменія - права на свободу та особисту недоторканність, свободу пересування, мирні зібрання; Перу - права на свободу та особисту недоторканність, права на повагу до приватного і сімейного життя, мирні зібрання, свободу пересування; Гватемала - свободу пересування, мирні збори. У своїй заяві з приводу відступів від зобов' язань за Пактом в умовах пандемії COVID-19 від 30 квітня 2020 року Комітет ООН з прав людини висловив занепокоєння тим, що деякі держави вдалися до надзвичайних заходів у відповідь на розповсюдження коронавірусу, які серйозним чином впливають на виконання ними своїх зобов' язань за Пактом, але при цьому офіційно не повідомили про дерогацію Генерального Секретаря ООН [10].

Десять держав-членів Ради Європи повідомили про відступ від зобов' язань за Конвенцією 1950 р. (Албанія, Вірменія, Естонія, Грузія, Латвія, Молдова, Північна Македонія, Румунія, Сан-Марино, Сербія), в більшості випадків обгрунтувавши свої обмежувальні спеціальні заходи декларацією ВОО3 від 11 березня 2020 року, якою спалах коронавірусу було оголошено пандемією [11]. Наприклад, Латвія відступила від зобов'язань з гарантування права на освіту, повагу до приватного і сімейного життя, свободи зібрань і об'єднань та пересування; Естонія - права на свободу і особисту недоторканність, справедливий суд, повагу до приватного і сімейного життя, свободи зібрань і об'єднань, права на власність, освіту, свободи пересування. Вірменія, Румунія та Сербія не зазначили конкретних положень Конвенції чи протоколів до неї, від яких здійснювали відступ. Натомість вони послалися на положення власної конституції, які гарантують право кожному на особисту свободу, свободу пересування, право на зібрання, право власності (Вірменія) або акти законодавства 
про введення надзвичайного стану у зв' язку з COVID-19, які передбачають можливість обмеження певних прав людини (Румунія). В заяві Сербії взагалі відсутні посилання на конкретні положення як Конвенції, так і національного законодавства. Станом на 31.05.2020 декілька держав уже оголосили про припинення надзвичайного стану (ситуації) та заходів, вжитих на підставі дерогації за Конвенцією (Естонія, Молдова, Румунія).

Дванадцять держав-членів Організації Американських Держав зробили заяви про відступ від своїх зобов'язань за Американською конвенцією з прав людини (Аргентина, Болівія, Гватемала, Гондурас, Домініканська Республіка, Еквадор, Колумбія, Панама, Парагвай, Перу, Сальвадор, Суринам). Більшість з цих держав у своїх заявах посилаються на положення не Конвенції, а власного законодавства щодо обмеження певних прав людини. Лише Чилі та Домініканська Республіка зазначають про відступ від конкретних положень Конвенції. Крім того, заява останньої є цікавою, оскільки держава відступила від своїх зобов' язань із забезпечення права на об'єднання не лише за Американською конвенцією з прав людини, але і за Міжамериканською конвенцією щодо попередження, покарання та ліквідації насильства над жінками, хоча сам документ не має положень про дерогацію.

Таким чином, стандарт «належної обачності» в умовах пандемії передбачає обов'язок держави вживати всіх необхідних заходів для забезпечення, перш за все, права на життя та здоров'я, попередження порушень прав людини та реагування на такі порушення внаслідок будь-якої діяльності, що здійснюється під її юрисдикцією або контролем, в тому числі з боку приватних осіб. Такі заходи включають надання всієї необхідної та наявної в розпорядженні органів влади інформації, пов'язаної із природою, ризиками від коронавірусу, засобами профілактики та лікування, даних епідеміологічних спостережень, застосування відповідних профілактичних та лікувальних заходів без дискримінації 3 метою $з$ надання необхідної медичної допомоги населенню. Міжнародні договори передбачають право для держав вводити окремі обмеження прав людини та робити відступ від своїх зобов'язань 3 ïx забезпечення в надзвичайних обставинах. Вони також закріплюють певні критерії та принципи, якими держави повинні керуватися у цих випадках задля уникнення можливих зловживань. Під час пандемії COVID-19 держави вдавались до обох інструментів.

Держави зобов'язані належним чином обгрунтовувати введення обмежувальних заходів, що втручаються в індивідуальні права та свободи людини, а міжнародні суди з прав людини - перевіряти легітимність цих обмежень, відповідність основним принципам та дотримання державами балансу між індивідуальними правами (наприклад, правом на свободу вираження поглядів) та суспільним інтересом (охорона здоров'я населення). Йовірно, що через декілька років Свропейський суд 3 прав людини, Міжамериканська комісія чи суд 3 прав людини або комітети ООН 3 прав людини змушені будуть оцінювати пропорційність, законність та необхідність заходів, що обмежують свободу пересування, право на особисту недоторканість, повагу до приватного життя, свободу вираження поглядів, право на освіту чи власність у справах, поданих проти держав, що ввели такі обмежувальні заходи у зв'язку із розповсюдженням коронавірусу. У випадку подання скарг про порушення індивідуальних прав під час надзвичайного стану, пов'язаного з COVID-19, державі-відповідачу, ймовірно, доведеться обгрунтовувати, що вжиті заходи обумовлювались ні чим іншим, як необхідністю боротьби з пандемією. Суди оцінюватимуть необхідність дерогації та заходів, вжитих на ії підставі, в кожному конкретному випадку. Вони приділятимуть увагу питанню, чи достатньо було застосувати звичайні обмеження прав людини, чи все-таки введення надзвичайного стану було виправданим, порівнюватимуть ситуацію щодо обмежень індивідуальних прав у різних державах. В будь-якому разі важливо пам'ятати, що сам факт того, що допустимий відступ від конкретного положення договору може бути виправданий гостротою певної ситуації, не скасовує вимоги до держави довести, що конкретні заходи, вжиті відповідно до дерогації, також зумовлюються гостротою цієї ситуації [2]. Іншими словами, держава повинна обгрунтувати не лише своє рішення про оголошення надзвичайного стану, але й будь-які конкретні обмежувальні заходи, вжиті на підставі такого оголошення.

1. Василенко В. А. Ответственность государства за международные правонарушения. Киев: Издательское объединение «Вища школа», 1976. 268 с.

2. CCPR General Comment No. 29: Article 4: Derogations during a State of Emergency adopted at the Seventy-second Session of the Human Rights Committee, on 31 August 2001.

3. CCPR/C/21/Rev.1/Add.11, General Comment No. 29. (General Comments). URL: https://www. refworld.org/docid/453883fd1f.html. 
4. CESCR General Comment No. 14: The Right to the Highest Attainable Standard of Health (Art. 12) adopted at the Twenty-second Session of the Committee on Economic, Social and Cultural Rights, on 11 August 2000 (E/C.12/2000/4). URL: https:/ / www.refworld.org/pdfid/4538838d0.pdf.

5. Coco A. and de Souza Dias T. Part I: Due Diligence and COVID-19: States' Duties to Prevent and Halt the Coronavirus Outbreak. EJIL: Talk! 24 March 2020. URL: https://www.ejiltalk.org/part-i-due-diligenceand-covid-19-states-duties-to-prevent-and-halt-the-coronavirus-outbreak/.

6. COVID-19 Guidance, 13 May 2020 / The Office of the UN High Commisioner for Human Rights. URL: https://www.ohchr.org/EN/NewsEvents/Pages/COVID19Guidance.aspx.

7. COVID-19 Response / 73rd World Health Assembly, A73/CONF./1. URL: https://apps.who.int/gb/ ebwha/pdf_files/WHA73/A73_CONF1-en.pdf.

8. McBride J. COVID-19 and the European Convention on Human Rights. ECHR Blog. URL: http:// echrblog.blogspot.com/2020/03/an-analysis-of-covid-19-responses-and.html.

9. Siracusa Principles on the Limitation and Derogation of Provisions in the International Covenant on Civil and Political Rights / United Nations, Economic and Social Council, U.N. Sub-Commission on Prevention of Discrimination and Protection of Minorities, Annex, UN Doc E/CN.4/1984/4 (1984). URL: https://www.icj.org/wp-content/uploads/1984/07/Siracusa-principles-ICCPR-legal-submission-1985eng.pdf.

10. Statement on derogations from the Covenant in connection with the COVID-19 pandemic / Human Rights Committee. 30 April 2020. CCPR/C/128/2. URL: https://www.ohchr.org/Documents/HRBodies/ CCPR/COVIDstatementEN.pdf.

11. Zghibarta P. The Whos, the Whats, and the Whys of the Derogations from the ECHR amid COVID-19. EJIL: Talk! 11 April 2020. URL: https://www.ejiltalk.org/the-whos-the-whats-and-the-whys-of-thederogations-from-the-echr-amid-covid-19/. 